\title{
Coastal Carrying Capacity for Mangrove Ecotourism Development, Case Study in Budo Village, North Minahasa Regency
}

\author{
Benny Irwan Towoliu*, Treesje Runtuwene, Dimas Ero Permana, Agustinus Lumettu, Maryke Alelo, Fonny Sangari \\ Tourism Department \\ Manado State Polytechnic \\ Manado, Indonesia \\ *benny.tourism@gmail.com
}

\begin{abstract}
Exploitation of new tourism site development happened in almost all places in Indonesia. Without a deep study of the environmental balance, the new tourist attraction is exposed through information technology network that resulted in the enslaving of visitors coming to the place. The decline in the quality of the natural environment and the disruption of sociocultural life is an indication to the unpreparedness of unexpected tourist locations through an appropriate plan. The purpose of this research is to analyse the carrying capacity of mangrove coastal area that will be used as ecotourism attraction, by taking case study at Budo Village, Wori Sub-district, North Minahasa Regency, which is also included in Bunaken National Park area. However, there has not been a study on the readiness of the carrying capacity of coastal areas as an ecotourism attraction. The Method of instrument used is the analysis of coastal environmental carrying capacity. The results of this study will be used by policy makers in planning the development of ecotourism and the determination of various tourist attractions that match the condition of the natural environment and social culture of local communities.
\end{abstract}

Keywords-coastal carrying capacity, mangrove ecotourism development

\section{INTRODUCTION}

Mangrove ecosystem area or known as mangrove forest is one of the ecosystems that are typical of the tropics and a small part in the sub-tropics. Unlike the general forest, the mangrove ecosystem forest is very small, where currently the mangrove ecosystem in the world is estimated to be 16 million ha remaining, and the largest in the world is in Indonesia with the highest biodiversity, and also has a coastline of $95.181 \mathrm{~km} 2$; Indonesia has a mangrove area of $3,489,140.68$ ha (in 2015). This amount is equivalent to $23 \%$ of the world's mangrove ecosystem, from a total area of 16,530,000ha. Of the mangrove area in Indonesia, it is known that an area of 1,671,140.75 $\mathrm{Ha}$ is in good condition, while the remaining area of $1,817,999.93$ ha is in damaged condition [1].

Even though the area of mangrove is small compared to the forest area in general, because it is only in the transition area between land and sea which makes it a buffer zone, but the mangrove ecosystem has a very complex function. The functions of mangrove ecosystems include: as a damper for ocean waves and storms, coastal protection from abrasion and erosion processes, sludge and sediment trapping, detritus producer, as a shelter and foraging for various species of brackish marine biota. Besides, it is a habitat for various wildlife such as birds, crocodiles, monkeys and snakes as well as bio filter for pollution and for preventing salt intrusion into terrestrial areas. In addition, mangroves are also a source of food and also as a medicinal plant as well [2]

Another function of the mangrove ecosystem is as a place of recreation or commonly referred to as a tourist attraction. In many places such as Java and Bali, mangrove ecosystems or mangrove forest areas have been used as tourist attractions such as: Pantai Indah Kapuk (Jakarta), Jungle Mangrove Wonorejo (Surabaya), Maron Mangrove Edupark (Semarang) and Mangrove Forest Objects Denpasar (Bali) and many other places on the islands of Java and Bali.

North Sulawesi saves a lot of coastal and ocean areas that are overgrown with mangroves, and there are even mangrove islands but have not been empowered as a tourist attraction. The location of mangrove forest areas such as that of in the Bunaken National Park area with a location of $\pm 68,000 \mathrm{Ha}$, with the five main islands, among others: Bunaken Island, Siladen Island, Manado Tua Island, Nain Island and Mentehage Island are islands that are overgrown with mangrove forests. Even about Mentehage Island, some forestry researchers, call it as the island that collects the most complete mangrove plantations, it's just very limited due to development as a tourist attraction in the national park area because the island is included in the jungle zone of the national park and is not allowed to be exploited as a tourist object and attraction.

North Minahasa Regency as one of the areas that is very close to the centre of the capital city Manado, has a lot of potential for mangrove forest ecosystems, for example in Budo Village. This village has the closest access both to the entrance to the national park area, namely Bunaken Island and the Capital of Manado Province which is only $30 \mathrm{~km}$ away. This village has extraordinary natural water potential, such as: (1) the existence of mangrove ecosystems, seagrasses and coral reefs, (2) the naturalness and authenticity of the area and, (3) 
the attraction and beauty of the underwater, where there are 3 diving spots (point diving) with the coast facing the national park area.

In 2015, the North Minahasa Regency Government approved the Medium-Term Village Development Plan (Rencana Pembangunan Jangka Menengah Desa RPJMDES), in which part of the mangrove forest area with a total area of \pm $62 \mathrm{Ha}$ was planned to be arranged and managed as a tourist attraction. Indeed, the local community had built before an infrastructure in the form of a bridge where tracking was done by visitors who wanted to enjoy the panorama of the beach and mangrove forest, but it has been damaged due to abrasion of sea water, and not managed properly. There are no visitor arrangements, even though the bridge that crosses the mangrove is built on community self-help. The form of selfhelp from the community to build a living area as a tourist village is a strong social capital in the process of empowering local communities. Research purposes to analyse the carrying capacity of coastal mangrove forests for ecotourism needs

\section{LITERATURE REVIEW}

\section{A. Ecotourism}

Ecotourism is a travel activity to visit the area of natural relatively undisturbed natural area, with the intention of really objectively see, learn, admire the face of natural beauty, flora and fauna including cultural aspects in both the past and the present that may be present in the region $[3,4]$. Meanwhile Weaver mentions: Ecotourism is a form of tourism that fosters learning experiences and appreciation of the natural environment, or some component thereof, within its associated cultural context [5]. It has the appearance (in concert with best practice) of being environmentally and socio-culturally sustainable, preferably in a way that enhances the natural and cultural resource base of the destination and promotes the viability of the operation. Compile three more basic concepts towards ecotourism operations [6], namely: (1) outdoor and natural areas that do not cause environmental damage, (2) this tourism prioritizes the use of transportation facilities that are created and managed by tourist area communities and (3) this tour takes great care of the natural environment and local culture. From these various opinions it can be concluded that ecotourism is a trip to tourist attraction, with no damage but tends to maintain and improve the tourist environment.

\section{B. Carrying Capacity in Ecotourism}

The carrying capacity of the environment is the ability of the environment to support human life and other creatures. Carrying capacity is a basic concept that is developed for the management of a natural and sustainable environment, through a measure of its ability. This concept was developed, especially for preventing damage or degradation from a natural and environmental resource. So that the existence, sustainability and function can be realized and at the same time and space, the user or community that uses the resource remains in good condition and / or not harmed [7]. In tourism, environmental carrying capacity is stated in number of tourists per unit area per unit time. But the breadth and time, generally cannot be averaged because the spread of tourists in space and time is not evenly distributed [6]. Recreational carrying capacity is the ability of a recreational area naturally, physically and socially to support the use of recreational activities and can provide the desired quality of leisure experience [8]. So the carrying capacity of tourism is the carrying capacity of bio-geophysics and socio-economic and cultural aspects of a location and / or tourism site in support tourism activities without causing a decline in environmental quality and satisfaction of tourists in enjoying the location and or tourist sites. The research that will be analysed is supporting mangrove forests for tourism needs. The carrying capacity of mangrove forests is the ability of mangrove forest resources to maintain functions and quality without reducing the ability to provide service facilities in the form of natural recreation and desired natural tourist [9].

\section{METHODS}

Carrying Capacity Analysis, an analysis intended for the development of marine tourism by utilizing the potential of coastal, coastal and island resources in a sustainable manner. The method used in calculating the carrying capacity of natural ecotourism development with the concept of Area Carrying Capacity (Daya Dukung Kawasan/DDK). Carrying capacity is the maximum number of visitors who can physically be accommodated in the area provided for certain invoices without causing disturbance to nature and humans. The formula for calculating the area carrying capacity (DDK) as follows [10].

Where:

$$
\mathrm{DDK}=\mathrm{k} \times \frac{\mathrm{LP}}{\mathrm{Lt}} \times \frac{\mathrm{Wt}}{\mathrm{Wp}}
$$

DDK = Area Carrying Capacity (person / day)

$\mathrm{K}=$ Ecological potential of visitors per unit area (people)

Lp = Length of area that can be utilized (m)

$\mathrm{Lt}=$ Unit area for certain categories

$\mathrm{Wt}=$ Time provided by the area for activities tours in one day (hours / day)

$\mathrm{Wp} \quad=$ Time spent by visitors for each certain activities (hours / days)

TABLE I. ECOlOGICAL Potential Visitors (K) AND THE AREA OF ACTIVITY (LT) [10]

\begin{tabular}{|l|l|l|l|}
\hline $\begin{array}{c}\text { Type of } \\
\text { Activity }\end{array}$ & $\begin{array}{c}\text { Visitor } \\
\text { (K) }\end{array}$ & $\begin{array}{c}\text { Unit of } \\
\text { area }\end{array}$ & \multicolumn{1}{c|}{ Explanation } \\
\hline $\begin{array}{l}\text { Mangrove } \\
\text { tourism }\end{array}$ & 1 & $50 \mathrm{~m}$ & $\begin{array}{l}\text { The track length is calculated, } \\
\text { each person is } 50 \mathrm{~m}\end{array}$ \\
\hline
\end{tabular}

The time for visiting activities (Wp) is calculated based on the length of time spent by visitors to carry out tourism activities. Visitor time is calculated with the time provided for the area $(\mathrm{Wt})$. Time of the area is the length of time the area is opened in one day, and the average working time is around 8 hours. 
TABLE II. PREDiction Time NeEded For MANGRove Tour

\begin{tabular}{|c|c|c|c|}
\hline No & Activities & $\begin{array}{c}\text { Time Required (Wp) } \\
\text { (hours/power) }\end{array}$ & $\begin{array}{c}\text { Total Time 1 } \\
\text { Day }\end{array}$ \\
\hline 1 & Mangrove tourism & 2 & 8 \\
\hline
\end{tabular}

\section{FINDING AND DISCUSSION}

Budo Village is a village located in Wori sub-district, North Minahasa regency, North Sulawesi province. This village is one of 20 villages in Wori sub-district which is $30 \mathrm{~km}$ from the district capital, and $4 \mathrm{~km}$ from the sub-district capital, $21 \mathrm{~km}$ from Manado which is the centre of the North Sulawesi provincial capital. Wori Sub district itself is one of the subdistricts in the North Minahasa regency which belongs to the poor sub-district category. Topographically, the location of Budo village is hilly, with an altitude of 0-400 meters above sea level with $70 \%$ air humidity and a minimum temperature of $29^{\circ} \mathrm{C}$ and a maximum temperature of $35^{\circ} \mathrm{C}$, an average temperature of $33^{\circ} \mathrm{C}$, and average rainfall $400-600 \mathrm{~mm}$.

Most of the land is used by the community as an agricultural and plantation area so that the average livelihood of the village community is farming and planting. The following are the potential of some of the potential of Budo village, among which are: (1) Natural resources, extensive agricultural land / land, water resources, (2) human resources, a considerable population with productive age, (3) existing infrastructure facilities such as village roads, school buildings and Paysandú, (4) production of agriculture/plantations, copra, cloves, nutmeg and home industry facilities such as furniture business, charcoal, souvenirs from wood and coconut fruits, (5) strategic geographical location, close to Bunaken National Park with the potential of mangrove forests and the smallest marine biota which is very suitable for the development of cottage or resorts, and (6) has the resources of the village government apparatus, PKK, Village Development Cadre, Paysandú Cadre , Health Cadres, Youth Organization and (7) has a social culture such as high community cooperation.

Specifically, for tourism potential, Budo village has an area of \pm 45 ha of mangrove forest, where there are fresh water sources in the location of mangrove forests, in addition to the location of marine parks and also around the waters there are beautiful coral reefs and rare marine biota. In the mangrove forest area there are several mangrove vegetation's that grow, including families Rhizophoraceae, Avicenniaceae, Sonneratiaceae, Avicennia marina, Bruguiera ghymnorhirza, Rhizophora apiculata, Rhizophora stylosa, Rhizophora mucronata, Ceriops tagal, Sonneratia alba, and Xylocarpus granatum. The condition of mangrove vegetation on the coast of Budo Village is relatively good, this is indicated by the number of mangrove species and densities that are quite high, as well as environmental factors that influence and support the mangrove community.

Currently, Budo village is visited by many local and foreign tourists. In general, they are interested in visiting because in the coastal area there are bridges that lead to the sea, which are built with the results of local community self-help. Many school children also visited by using the bus. They generally do activities such as swimming and snorkelling, while foreign tourists usually do diving. There are currently three diving spots. Budo village government has built facilities for trekking/around the mangrove forest area, by seeing the increasing number of visitors coming to the area to keep the area safe and not damaged, it is necessary to calculate the value of visitor capacity to enter the mangrove forest area. The plan is that there will be four trajectories to be built with the following trajectory conditions border one along (1) the water and three (3) other trails along the land. Especially going through the coastal will use boats provided by local residents.

The following results of the calculation of carrying capacity for each track.

TABLE III. VALUE OF AREA CARRYING CAPACITY

\begin{tabular}{|l|l|l|l|l|}
\hline No & Location & $\begin{array}{c}\text { Tracking } \\
\text { Purposes }\end{array}$ & $\begin{array}{c}\text { Area Carrying } \\
\text { Capacity }\end{array}$ & $\begin{array}{c}\text { Total } \\
\text { Person Per } \\
\text { Day }\end{array}$ \\
\hline 1 & Coastal & 1 & 102 & 102 \\
\hline \multirow{2}{*}{2} & \multirow{2}{*}{ Mainland } & 2 & 29 & \multirow{2}{*}{82} \\
\cline { 3 - 4 } & & 3 & 25 & \\
\cline { 2 - 4 } & 4 & 28 & \multicolumn{2}{|l}{} \\
\hline
\end{tabular}

Ecotourism activities in Budo Village, must pay attention to the carrying capacity of the area. There is one track that is carried out through the coastal with a total of 102 visitors per day. The time provided for activities on this track is 4 hours a day, taking into account the average length of sea tide. This track can be traversed using transportation equipment such as rowing, canoe or small boats. Other facilities that must be considered are buoys for the safety of passengers/visitors. This track also requires a small dock as a place to lean on the boat, but now in the village of Budo there is a dock that is usually used by fishermen, so it has made it easier for the village to develop this attraction. Other activities that can be carried out on this track besides enjoying the beauty of mangroves, there can also be carried out activities such as fishing, photography, water sports (rowing or canoe) and bird watching.

Special track land that runs along the mainland enjoys mangrove ecosystems. The number of visitors who can enjoy this land track activity is 82 people with a visit time of 8 hours per day, this activity is not influenced by tidal conditions, with consideration of the boardwalk adjusted to the conditions of tides. The facilities and infrastructure needed in this activity 8 , the boardwalk. This activity will provide experience to visitors such as: walking in the middle of a mangrove forest, observing the types of mangrove species, birds and other endemic fauna that live in mangrove forests. By considering the value of this carrying capacity, it will affect the sustainability of the mangrove forest area in Budo village, and also determine the sustainability of an ecotourism activity. The carrying capacity of each region is different from one region to another and is related to the type of tourism activities that will be developed. Therefore, the carrying capacity of mangrove ecosystems needs to be considered in the development of an ecotourism area.

\section{CONCLUSION}

From the discussion, it can be concluded that to preserve the ecotourism and mangrove forest tourism objects, the village government through ecotourism management must take into account the carrying capacity of the ecotourism area. The 
carrying capacity of ecotourism can still be adjusted to track changes that will be made by the manager. In addition to measuring the carrying capacity, it is also necessary to assess the feasibility of a site as an attraction for ecotourism by measuring real potential and visitor ratings, so that the development of ecotourism projects can succeed [11,12]. In the future, the village government needs to build a shared commitment to safeguard the mangrove forest ecosystem, the development of various other attractions must always pay attention to the carrying capacity of the area. To add other activities such as swimming, boating, picnics and camping in an ecotourism area requires the calculation of its own carrying capacity, so that further research is needed.

\section{ACKNOWLEDGMENTS}

The authors are highly grateful to the State Polytechnic of Manado for funding this research.

\section{REFERENCES}

[1] Ministry of Environment and Forestry Indonesia, Miliki 23\% Ekosistem Mangrove Dunia, Indonesia Tuan Rumah Konferensi Internasional Mangrove 2017, 2017, [Online] http://ppid.menlhk.go.id/berita_foto/browse/592.

[2] H. Ghufron and K.M. Kordi, Ekosistem Mangrove:potensi, fungsi dan pengelolaan, Jakarta: Rineka Cipta, 2012.
[3] Lascurian, "Tourism Ecotourism and Protected Areas," Tourism Workshops held the IV World Congress on National Park and Protected Areas, Caracas Venuzuela, 1996.

[4] D.E. Linberg and K. Stavenga, Ekonomi Pariwisata, Jakarta; PT. Gramedia Putaka Utama. 1995.

[5] D.B. Weaver, "The evolving concept of ecotourism and its potential impacts," International Journal of Sustainable Development, vol. 5, no. 3, pp. 251-264, 2002.

[6] J. Damanik and F.W. Helmut, Perencanaan Ekowisata: dari Teori ke Aplikasi, Yogyakarta: Andi Offset, 2006.

[7] C. Clivaz, Y. Hausser, and J. Michelet, Tourism Monitoring System Based On The Concept of Carrying Capacity: The Case of The Regional, 2004.

[8] R. Manning, "Research to Estimate And Manage Carrying Capacity of Tourism Atraction: A Study of Alcatraz Island," Journal Of Sustainable Tourism, vol. 10, no. 5, 2002.

[9] K. Brown, R.K.T.H Hameed, and I. Bateman, "Environmental Carrying Capacity and Tourism Development International Maldives and Nepal," Journal Environmental Conservation, vol. 24, no. 4, pp. 316-324, 1997.

[10] F. Yulianda, Ekowisata bahari sebagai alternative pemanfaatan sumber daya pesisir berbasis konservasi, Departemen Manajemen Sumber Daya Perairan, FPIK. IPB. 2007.

[11] B.I. Towoliu, D.E. Permana, M.D. Gahung, and A. Lumettu, "Ecotourism Village Feasibility Assessment Analysis: The Case of Bahoi Village, in North Minahasa Regency, Indonesia," AlmatourismJournal of Tourism, Culture and Territorial Development, vol. 9, no. 17, pp. 137-152, 2018.

[12] B.I. Towoliu and M.E. Takaendengan, "Perception of Tourist towards the Potential Development of Tumpa Mountain Area as Integrated Ecotourism, Manado, North Sulawesi Province,' Journal of Indonesian Tourism and Development Studies, pp. 1-10, 2015. 